Jurnal Keuangan dan Perbankan, 21(3): 344-355, 2017
Nationally Accredited: No.040/P/2014
http://jurnal.unmer.ac.id/index.php/jkdp

\title{
Dividend Policy and Corporate Value (A Meta-Analysis)
}

\author{
Tifani Titah Dwi Tyastari, Rosidi, Erwin Saraswati \\ Department of Accounting Faculty of Economics and Business University of Brawijaya \\ Jl. M.T. Haryono No.165 Malang, 65145, Indonesia
}

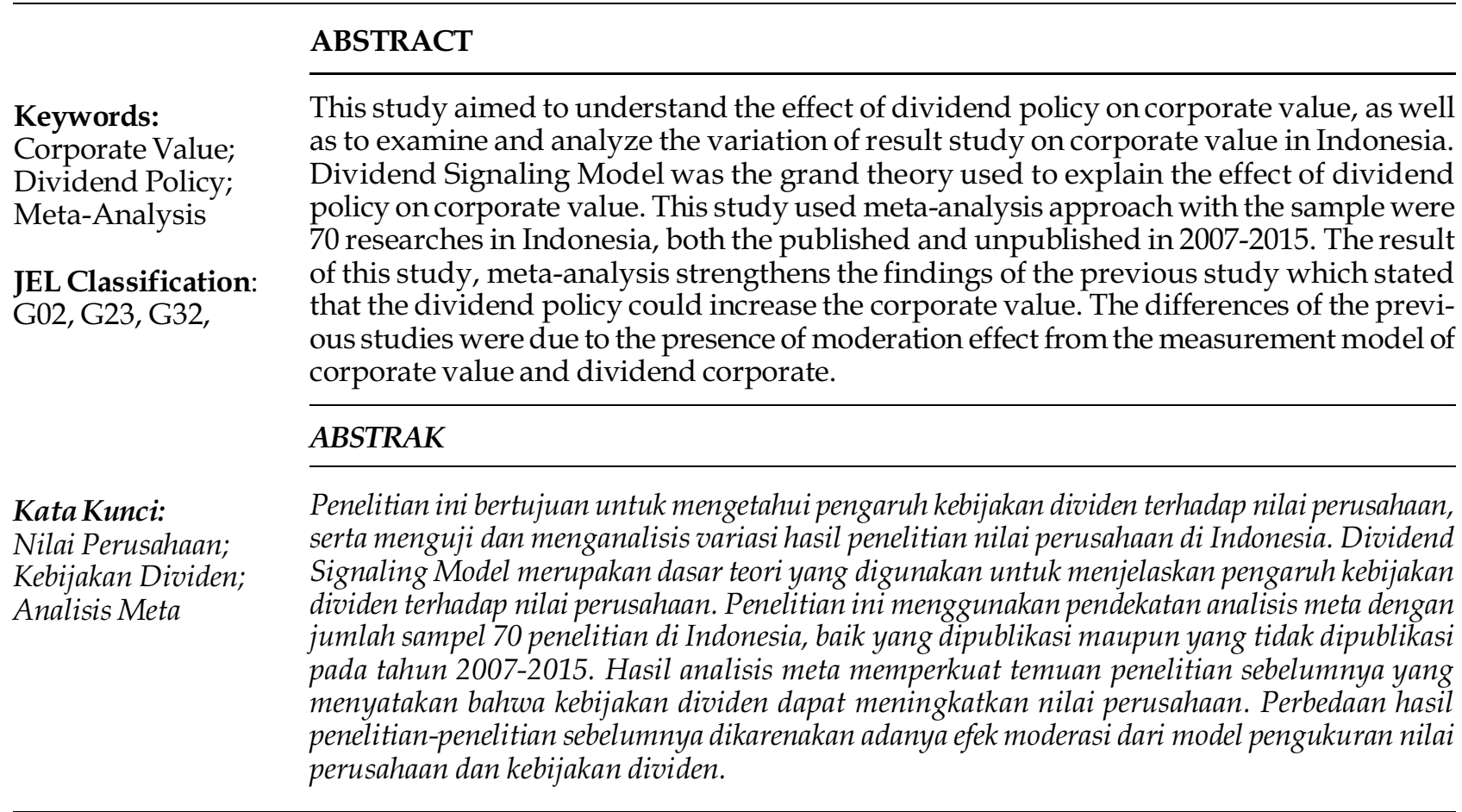

Corresponding Author:

Tifani Titah Dwi Tyastari: Tel. +62 341555 000; Fax.+62 341553834

E-mail: tifanititah@gmail.com

ISSN:2443-2687 (Online) ISSN:1410-8089 (Print) 


\section{Dividend Policy and Corporate Value (A Meta-Analysis)}

Tifani Titah Dwi Tyastari, Rosidi, Erwin Saraswati

Corporate value is investor perception toward corporate level of success (Mesrawati, 2013). The increasing level of corporate value will also increase the investor trust to corporate prospect in the future. The company could take strategic step in obtaining high corporate value. According to Hashemijoo et al. (2012), the important decision in funds management of the company is the profit distribution, which is shared as dividend or investment for other investment chance. If manager choose to distribute the profit to the shareholders as dividend, it is important to consider how big the proportion shared and the proportion returned to the company. Investment and funds decision will affect the company vision in the future.

Based on the Dividend Signaling Model, dividend tends to affect positively toward the corporate value. The aim of investing is not only to get capital gain, but also to expect the company dividend sharing. Based on those things above, the company which regularly share their dividend will increase the interest of the investor to invest in that company. The increase number of investor interest will also affect the corporate value.

This study focuses on dividend policy strategy, because previous studies stated inconsistent results the effect of dividend policy on corporate value. Several studies have found that dividend policy has a positive effect on corporate value (Agustina, 2011; Artini \& Puspaningsih, 2011; Putri, 2011; Hutami, 2012; Instanti, 2013; Juhandi, 2013). In contrast, another study found that dividend policy has a negative effect on corporate value (Rakhimsyah \& Gunawan, 2011; Harahap \& Wardhani, 2012; Rahmandia, 2013). Other studies stated that dividend policy does not affect the corporate value (Dossugi 2009; Sofyaningsih \& Hardiningsih, 2011; Putri, 2013; Bakti, 2014).

According to Eny (2013), when experience such a case, the power to examine the validity and generalizability of substantial research that has been carried out in a field of study, research must be done by using Meta-Analysis. Meta-Analysis is a study on a number of research results in the same problem, then summarized and analyzed, so that we will get a conclusion on the problem-solving (Glass, 1976). One of the conditions required to perform meta-analysis is the assessment of the results of similar research (Tawi, 2008).

The use of meta-analysis in this study tries to figure measurements (proxy) the most appropriate one for a dividend policy variable and the variable of corporate value, resulting in a correlation in accordance with the Dividend Signaling Model and conditions in Indonesia. Test that carried out on the meta-analysis is the moderating effects test. Moderating effects test used to see the consistency of the research data, and then analyzed the inconsistencies caused by the measurement of different variables. This study uses a dividend policy variable measurement and corporate value variable measurement.

There are several reasons that motivate to conduct this study by meta-analysis approach. First, research on the effect of dividend policy on corporate value is already a lot but, with varied results. So the meta-analysis is a good tool to find the appropriate conclusion regarding the focus of the research. Second, the meta-analysis is the most objective method and approach towards quantitative in terms of research that uses methods of study articles or reviews (Tawi, 2008). The focus on meta-analysis is the data, not the conclusion of the study. So the result of the estimated effect of dividend policy on corporate value is more reliable and trustworthy. Third, there is a relatively lack of studies with meta-analysis approach in the field of accounting, particularly in Indonesia.

This study aims to examine and analyze the effect of dividend policy on corporate value by using meta-analysis. Another purpose of this study is to examine and analyze the variations in the research results on corporate value in Indonesia due to the moderating effect of the measurement model of corporate value and dividend policy. 


\section{Jurnal Keuangan dan Perbankan | KEUANGAN}

Vol. 21, No. 3, Juli 2017: 344-355

Effect of dividend policy on corporate value is based on the Dividend Signaling Model. Dividends as a signal for the company tend to be used to describe the provision of information to the market, not to mention about the optimal dividend policy (Weston \& Copeland, 1997). High dividend payment announcement can be interpreted as a positive signal for investors because the high dividend shows that the company is confident of future cash flows which are large enough to cover the dividend rate.

Manager as the company's internal parties is better informed about the company in more detail than with external parties (shareholders). The gap of information (asymmetric information) between the 2 sides will be difficult for investors to assess the company's quality objectively. One way that the company can do to overcome this is to pay dividends to shareholders (Megginson, 1997; Weston \& Copeland, 1997; Arifin, 2005; Manurung, 2012; Gumanti, 2013; Engombe, 2014).

Meta-analysis is a statistical technique that is involved in extracting and combining data from previous research results to produce a summary (Hunter \& Schmidt, 1990; Ahmed \& Courtis, 1999; Fanani, 2016). According to Glass (1976), metaanalysis can be interpreted simply as an analysis of the analysis. Meta-analysis seeks to examine and analyze several similar studies with results that may vary, so it can produce a conclusion on differences in the study.

Meta-analysis is a research method literature review with a quantitative perspective. In the meta-analysis, it is performed a collection of articles on the same topic, but there are gaps in it. Then, it is conducted the analysis the effect size based on statistical results of the data contained in the article. Meta-analysis can also test the moderating effects in a study, so it can be known whether the gap caused by the measurement of certain variables that moderate the relationship between variables.
Meta-analysis is a good tool to address problems in this study. Meta-analysis is able to explain the influence of dividend policy and corporate value. Meta-analysis is also able to explain the moderating effects that may lead to differences in the results of research on the impact of dividend policy on corporate value. In this study, using dividend policy and corporate value as a measurement variable in the test the moderating effects.

\section{HYPOTHESES DEVELOPMENT}

\section{The Effects of Dividend Policy on Corporate Value}

According to Lintner (1956) one of the important factors that determine the dividend policy change is the company's profit. In order for the payment of dividends can take place smoothly, then the manager develop a dividend policy that is based on the amount of profits from the company. It was concluded that a stable dividend payments will impact on the increased interest of investors to invest in the company, so it will automatically increase the value of the company.

According Aharony \& Swary (1980) when the dividend is reduced, then the stock price decreased. The findings support the notion that there is a strong correlation betweendividends and the stock price. Kostyuk (2006) examined the effect of dividend policy determined by the company on corporate value is reflected in the stock price. As a result, in all categories, the dividend policy has positive effect on corporate value. Murekefu \& Ouma (2012) conducted a study on the effect of dividend policy on firm performance (value companies) in Kenya. The study states that the dividend policy has positive influence on the performance of the company.

Ansori \& Denica (2010), Wijaya (2010), Martikarini (2012), Fenandar (2013), and Sari (2013) conducted a study on the effect of dividend policy on corporate value using a second proxy variables 


\section{Dividend Policy and Corporate Value (A Meta-Analysis) \\ Tifani Titah Dwi Tyastari, Rosidi, Erwin Saraswati}

are similar. Dividend policy used DPR as the proxy, while the value of the company used PBV as the proxy. The results showed that the positive effect of dividend policy on corporate value.Some of these studies explain that the dividend policy has positive influence on the value of the company in accordance with the Dividend Signaling Model. Based on some earlier research, it can be hypothesized as follows:

$\mathrm{H}_{1}$ : Dividend policy has positive effect on corporate value.

\section{Moderator Variable Analysis on the Correlation between Dividend Policy and Corporate Value}

Research on the effect of dividend policy on corporate value has a lot to do. Rakhimsyah \& Gunawan (2011) and Harahap \& Wardhani (2012) investigated the effect of dividend policy on corporate value using DPR proxy for dividend policy and PBV for the corporate value. However, in contrast to other studies (Ansori \& Denica, 2010; Wijaya, 2010; Martikarini, 2012; Fenandar, 2013; Sari, 2013), the results of the study stated that the dividend policy negatively affect the corporate value.

Some studies suggest that dividend policy does not affect the corporate value (Dossugi, 2009; Hardiningsih, 2009; Sofyaningsih \& Hardiningsih, 2011; Ningsih \& Indarti, 2012; Gayatri \& Mustanda, 2014; Ulya, 2014; Abdullah, 2016). Those research using the same proxy, the Dividend Payout Ratio (DPR) for the dividend policy and Price to Book Value (PBV) for the value of the company.

Based on the explanation, the conclusions about the effect of dividend policy on corporate value still cannot be known certainly. It needs to do more research on the causes of differences in the results, derived from the measurement model of the dividend policy or the corporate value measurement model. That is because, in previous stud- ies, both the dividend policy and the corporate value using different measurements. Based on the presentation, the proposed hypotheses is as follows:

$\mathrm{H}_{2 \mathrm{a}}$ : The effect of dividend policy on corporate value is moderated by the measurement model on corporate value.

$\mathrm{H}_{2 b}$ : The effect of dividend policy on corporate value is moderated by the measurement model on dividend policy.

\section{METHODS}

This study uses literature review approach to assessing the results of research on the effect of dividend policy on corporate value. This study used meta-analysis as an analytical tool that aims to obtain answers to the inconsistency of results of previous studies on the effect of dividend policy on corporate value. The study will analyze the results of research on the effect of the dividend policy on the corporate value in Indonesia for 9 years from 2007-2015. Because at that period, the research on it has more to do with include complete data for research purposes meta-analysis. Therefore, this period is considered adequate and representative in capturing the development of a research.

The data used in this research is secondary data in the form of research articles about the effect of dividend policy on the corporate value in Indonesia both published and non-published in Indonesia. The use of unpublished research data is to test the sensitivity of the study. Whether the results of this study are influenced by the type of publication of the research or not. In addition, the data used comes from scientific research in the form of thesis and dissertation from the University in Indonesia.

The research objects included in the metaanalysis in this study have the following characteristics: (1) a study of firm value focused on ex- 


\section{Jurnal Keuangan dan Perbankan | KEUANGAN}

Vol. 21, No. 3, Juli 2017: 344-355

amining the relationship between dividend policy and firm value quantitatively; (2) research on the value of a company that places the proxy of firm value as a dependent variable; (3) the independent variables included in the analysis are determined based on the amount of research sufficient to perform the meta analysis and which have different research results, namely dividend policy; and (4) the statistical summary reported in such studies should not be a correlation coefficient (r) to the relationship of dividend policy to firm value, but it could be if other reported statistics can be transformed into statistical $r$, such as t-statistic or p-value (Hunter \& Schmidt, 1990; Lipsey \& Wilson, 2001).

This study uses a sampling judgment in determining the object of research. Judgment sampling is done if investigators determine the object of the selected sample based on the evaluation (judgment) of the researcher (Eny, 2013). The data of dividend policy and corporate value is obtained from the statistical data of the research sample. According to Hunter \& Schmidt (1990), Ahmed \& Courtis (1999), and Eny (2013), the steps in conducting the analysis of data in meta-analysis method are: (1) developing appropriate data to research topics; (2) selecting data in accordance with the research needs; (3) identifying the variables used in the study; (4) statistical analysis (meta-analysis techniques); and (5) sensitivity analysis.

In the meta-analysis, there is a moderation variable testing technique. The moderation variable is a variable that causes a difference in the correlation between 2 other variables (Ahmed \& Courtis, 1999). This study used Chi-square test based on Hunter \& Schmidt (1990) to determine moderation variable. If the Chi-square test yields insignificant value, it means that the result of the analyzed research is homogeneous, it gives indication of no moderation variable. So it can be concluded that the difference between that correla- tions is statistical error and not the functional errors of some moderating variables (Ahmed \& Courtis, 1999). If the Chi-square test produces a significant value, it means heterogeneity occurs, so it is necessary to enter the moderation variable.

That is, variations of existing research results are moderated by other variables. This study will use measurement as a moderating variable, both for proxy dividend policy and firm value. The effects of moderation variables were done by sub-grouping the studies and calculating $r$ (correlation coefficient) and $S^{2} r$ (variance total) for each sub-group hypothesis. Sub-group classification is done according to different measurement of dependent variable and independent variable. The purpose of this subgroup is to reduce heterogeneity and to increase explanatory strength (Lyons, 2002; Ahmed \& Courtis, 1999).

\section{RESULTS}

During the study period (2007-2015), it is collected 156 researchs appropriate to the topic of the influence of dividend policy on corporate value. The study was then selected to find studies with complete data in accordance with the needs of a meta-analysis. After select the research, collected 70 samples of research (see Appendix 1) in accordance with the required criteria.

Explanatory variables in this study using a variable dividend policy. Based on the results of meta-analysis, table 1 of 74 studies that examine the effect of dividend policy and the corporate value, generating an average correlation (]$)=0.0745$ with a confidence interval of 95 percent (from 0.0111-0.1378). These results indicate that the dividend policy positively and significantly affects on the corporate value, so it can be said that hypothesis $1\left(\mathrm{H}_{1}\right)$ can be accepted.

Based on calculations Chi Square $\left(\mathrm{X}_{\mathrm{k}-1}\right)$, obtained value of 427.5249 . The value is greater than 


\section{Dividend Policy and Corporate Value (A Meta-Analysis)}

Tifani Titah Dwi Tyastari, Rosidi, Erwin Saraswati

the value of Chi Square table $\left(\mathrm{X}_{0,01}^{2}\right)$, namely 102.8163. It indicates the moderating effects that affect the relationship between the dividend policy and corporate value. Therefore, to know the whereabouts of the moderating effect required sub-group analysis of the measurement model of the dividend policy and corporate value.

\section{Meta-Analysis on the Moderator Effect (Sub-group Analysis)}

Based on the results of Chi Square test that was done previously, the value of Chi Square count is greater than the value of Chi Square table $\left(\mathrm{X}_{k-1}^{2}>\right.$ $\left.\mathrm{X}^{2}{ }_{0,01}\right)$. So we can say there is a moderating effect between dividend policy and corporate value. Table of Meta Sub-group describes the effect of moderating the enterprise value measurement model and the measurement model dividend policy.

The results of the sub-group that carried out the measurement of the value of enterprise variable (the dependent variable), the PBV, Closing Price, Tobin's Q, PER, MVE, and Realized Return varied. Based on research data samples in accordance with predetermined criteria, the measurement of the corporate value that is widely used is the PBV. Table 2 measurements using PBV, Tobin's $\mathrm{Q}$, and MVE indicate a significant relationship between the dividend policy and the corporate value in the same direction with the general results of meta-analysis (positive). Measurement of the corporate value using Realized Return also indicates a significant relationship between the dividend policy and the corporate value, but in the opposite direction to the general results of meta-analysis, which is negative. Measurement of the corporate value using the Closing Price and PER indicates the effect was not significant between the dividend policy and corporate value. The mixed results indicate the effect of moderating effects between the dividend policy and the corporate value, so it can be said hypothesis $2 \mathrm{a}\left(\mathrm{H}_{2 \mathrm{a}}\right)$ can be approved.

Measurement of a dividend policy variable (independent variables), namely DPR, DPS, Dummy, and DY, also a moderator for the effect of sub-group analysis results varied. Based on research data samples in accordance with predetermined criteria, measurement dividend policy that is widely used is the DPR. Measurement dividend policy by using the DPR and Dummy indicated a significant positive effect between the dividend policy and the corporate value, in accordance with the general results of meta-analysis. Another measurement using DPS and DY indicates the result is not significant because the minimum and maximum values (confidence interval) indicate positive and negative values. The results of the sub-group based on the measurement of the independent variables vary, so it can be concluded that there is a moderating effect between the effects of dividend policy on corporate value. Based on this it can be said hypothesis $2 \mathrm{~b}\left(\mathrm{H}_{2 \mathrm{~b}}\right)$ is approved.

\section{DISCUSSION}

\section{The Effect of Dividend Policy on Corporate Value}

Results of general meta-analysis in this study proves that the dividend policy of significant positive effect on corporate value. This is consistent with the hypothesis put forward earlier $\left(\mathrm{H}_{1}\right)$. Ad-

Table 1. Meta-Analysis Results (General Meta-Analysis)

\begin{tabular}{ccccccccc}
\hline & $\sum \mathbf{N i}$ & K study & $\mathbf{r}$ & Min & To & Max & $\mathbf{x}^{2}{ }_{\text {k-1 }}$ & Description \\
\hline General Meta-Analysis & 10816 & 74 & 0,0745 & 0,0111 & - & 0,1378 & 427,5249 & Significant \\
\hline
\end{tabular}

Source: Data Processing 


\section{Jurnal Keuangan dan Perbankan | KEUANGAN}

Vol. 21, No. 3, Juli 2017: 344- 355

ditionally, result of a meta-analysis is also consistent with the Dividend Signaling Model theory and dividend policy phenomenon in Indonesia. It explains that the higher dividends paid by the company, investors will be interested to invest in these companies, so the corporate value will increase.

The result of meta-analysis in this study correspond to individual research conducted by Kostyuk (2006) and Murekefu \& Ouma (2012) which states that the positive effect of dividend policy on corporate value. Moreover, the results also correspond with individual research in Indonesia that retrieves data from an Indonesian company that is more relevant.

According to Ansori \& Denica (2010), dividend policy significant positive effect on corporate value. A manager should be able to meet the interests of both companies and the shareholders in determining the optimal dividend policy. The decision to pay dividends to shareholders must be accompanied by a decision to withhold part of your profits as a reserve investment. If the dividend paid by the company is large enough, then the company must seek external funding to meet the needs of investment funds. Conversely, if dividends were paid little, then the company's reserve fund will be large enough. However, it should also be remembered that the reserve fund substantial investment in the company will increase the possibility of agency problems between the managers and shareholders of the company. Therefore, the proportion of the dividends paid and the amount of reserves must be balanced investment funds, so as to benefit both management and shareholders, which will affect the determination of the value of the company.

Wijaya (2010) states that the dividend policy has positive effect on corporate value. It is based on the assumption that the dividend policy is important for the company to meet shareholder wealth, but on the other hand does not hamper the company's performance. In accordance with the signaling theory, the dividend contains information about the company's prospects in the future. Announcement of increasing dividend has increased stock returns and can be used to coun-

Table 2. Meta-Analysis Result (Meta Sub-group)

\begin{tabular}{|c|c|c|c|c|c|c|c|c|c|}
\hline & & $\sum \mathbf{N i}$ & K study & $\mathbf{r}$ & Min & to & Max & $x 2$ & Description \\
\hline & $\begin{array}{c}\text { General Meta- } \\
\text { Analysis }\end{array}$ & 10816 & 74 & 0.074455 & 0.011100 & - & 0.1378104 & 427.5249 & Significant \\
\hline \multirow{6}{*}{ 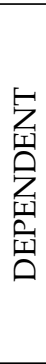 } & PBV & 6003 & 48 & 0.092692 & 0.038894 & - & 0.1464904 & 215.6383 & \multirow{6}{*}{$\begin{array}{l}\text { Significant } \\
\text { Not } \\
\text { Significant } \\
\text { Significant } \\
\text { Not } \\
\text { Significant } \\
\text { Significant } \\
\text { Negatively } \\
\text { Significant }\end{array}$} \\
\hline & Closing Price & 1857 & 9 & 0.080321 & -0.055582 & - & 0.2162247 & 139.4394 & \\
\hline & Tobin's Q & 732 & 6 & 0.061055 & 0.033736 & - & 0.0883747 & 16.2792 & \\
\hline & PER & 525 & 5 & 0.043077 & -0.064855 & - & 0.1510096 & 34.0180 & \\
\hline & MVE & 1404 & 3 & 0.039714 & 0.032308 & - & 0.0471218 & 8.3225 & \\
\hline & $\begin{array}{l}\text { Realized } \\
\text { Return }\end{array}$ & 295 & 3 & -0.079140 & -0.082671 & - & -0.0756104 & 3.5380 & \\
\hline \multirow{4}{*}{ 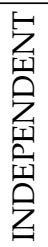 } & DPR & 7726 & 63 & 0.066295 & 0.012677 & - & 0.1199137 & 276.2245 & \multirow{4}{*}{$\begin{array}{l}\text { Significant } \\
\text { Not } \\
\text { Significant } \\
\text { Significant } \\
\text { Not } \\
\text { Significant }\end{array}$} \\
\hline & DPS & 312 & 3 & 0.424644 & -0.052969 & - & 0.9022575 & 116.1590 & \\
\hline & Dummy & 912 & 3 & 0.162917 & 0.168161 & - & 0.1576727 & 0.4249 & \\
\hline & DY & 613 & 3 & 0.005185 & -0.034641 & - & 0.0450134 & 15.4569 & \\
\hline
\end{tabular}

Noted: Sig. $=0.05$ 


\section{Dividend Policy and Corporate Value (A Meta-Analysis)}

Tifani Titah Dwi Tyastari, Rosidi, Erwin Saraswati

teract the issues that are not expected in the foreseeable future (Aharony \& Swary, 1980).

The results of this study have shown that the dividend policy affect the corporate value. The majority research in Indonesia used fundamentalbased, using financial ratios as a measure of value and dividend policy. However, when seen in real conditions in the capital markets in Indonesia, investors tend to look at the technical factors of a company's shares other than fundamental factors. Technical factors are stock movements during some periods. It can be a benchmark for investors in determining trading decisions. In this study, the effect of dividend policy on corporate value is explained by fundamental factors because the data sample used entirely using ratios. Explanations based on technical factors can be done by inserting a study that tested the effect of dividend policy on corporate value by observing the movement of stocks. However, in Indonesia, the research is still lacking so it cannot be conducted meta-analysis.

\section{The Effect of Dividend Policy on Corporate Value Moderated by the Measurement Model on Dividend Policy and Corporate Value}

Based on the results of meta-analysis, it is evident that the influence of dividend policy and corporate value measurement models moderated by dividend policy and the corporate value measurement model. It can be seen from the results of an inconsistencies meta-subgroup, both for measurement of dividend policy and the measurement of corporate value. This means that the measurement of the dividend policy and the measure of the corporate value affect the results of previous studies.

For example, research with different corporate value measurement performed by Fenandar (2013), which uses DPR for the measurement of dividend policy and PBV for measuring the cor- porate value. The study stated that the dividend policy has positive effect on corporate value. The opinion in accordance with the Dividend Signaling Model where the dividend policy is a signal given by the company to certify that the company is in good condition.

Another study conducted by Bernandhi (2014), using the DPR for the measurement of dividend policy and Tobin's $Q$ as a measurement of the corporate value. The results of the study stated that the dividend policy does not affect the corporate value, in accordance with the Dividend irrelevance Theory (MM Theory) expressed by Modigliani \& Miller (1989). According to the results, the dividend policy is not a factor that contributed significantly to the corporate value. Capital gain more attractive to investors because of lower taxes and an expected major objective of the investment in a company

Unlike the previous studies, the research that was done by Haruman (2008) was using the MVE for measuring the value of the company, while the dividend policy for the measurement using the DPR. The results of the study stated that the dividend policy negatively affect the corporate value. It is based on the assumption that the lower dividend payment will increase the corporate value due to increase reserves investment, so as to grow the company through investment projects (especially for growing companies).

Studies using different measurement dividend policy, so that research results can varied, the research done by Prathama (2013). The study used two kinds of measurements that the dividend policy DY and Dummy, while the measurement of the corporate value was using the PBV. The results using measurements DY stated that dividend policy does not affect the value of the company. While for measurement Dummy, dividend policies negatively affect the value of the company. The inconsistent results make it clear that the difference in the measurement variable is the cause 
of the inconsistency of the results of research on the relationship between the dividend policy and corporate value.

Another study using a different measurement of dividend policy and the conclusion is the dividend policy has positive effect on corporate value. The study was conducted Juhandi (2013) were used Tobin's $Q$ as a measurement of the value of the company and Dividend Payout Ratio (DPR) for the measurement of dividend policy.

The difference results of these studies due to variations in the measurement value of the company. After analyzing the effects meta-moderation, it can be concluded that both the measurement model of the dividend policy and corporate value may be moderating variable relationship between the 2 variables. Based on the research sub-group moderating effects, significant positive results in accordance with the general meta-analysis is the PBV, Tobin's Q, and MVE for enterprise value measurement model. Measurement model is a significant positive dividend policy according to the general meta-analysis is the DPR and the Dummy. These ratios can be taken into consideration for the company in determining the optimal dividend policy so as to increase the value of the company. Investors can also pay attention to the ratios in the financial statements of companies to choose a company that has a high prospect of generating the maximum profit.

\section{Sensitivity Analysis}

The results of meta-analyzes on the publication status on the Table 3 stated there was no publi- cation bias between study published by research that is not published. Consistent with the general results of meta-analysis, the results of the analysis of the average correlation (]) for the publication of research is 0.0995 , whereas for the non-publication research is 0.0608 .

Based on these results it can be concluded that the effect of dividend policy on corporate value is not affected by the type of studies, both published and unpublished. Quality of studies is one of the things that can lead to publication bias in meta-analysis. Therefore, non-published research may be control in the meta-analysis, so that the research publishing bias can be overcome.

\section{CONCLUSION AND SUGGESTIONS}

\section{Conclusion}

After a meta-analysis on the effect of dividend policy on corporate value, there are several findings which are the conclusions of this study. The results of the study found that: (1) in general, dividend policy can increase the corporate value. The results are consistent with the theory of the Dividend Signaling Model by Bhattacharya (1979). The findings show that in Indonesia, in general, an increase in dividend payment followed by a rise in the value of the company. Investors like companies that pay dividends on a regular basis because it shows that the company will be able to improve the life of the shareholders. However, the result of this research focuses on fundamental aspects, namely financial ratios to determine the effect of dividend policy on corporate value.

Table 3. Meta-AnalysisPublishing Status

\begin{tabular}{|c|c|c|c|c|c|c|c|}
\hline & $\sum \mathbf{N i}$ & K study & $\mathbf{r}$ & Min & To & Max & $\mathrm{x}^{2} \mathrm{k}-1$ \\
\hline General Meta-Analysis & 10816 & 74 & 0.0745 & 0.0111 & - & 0.1378 & 427.5249 \\
\hline Publishing & 3825 & 32 & 0.0995 & -0.0154 & - & 0.2144 & 260.7189 \\
\hline Non Publishing & 6991 & 42 & 0.0608 & 0.0266 & - & 0.0949 & 164.7473 \\
\hline
\end{tabular}




\section{Dividend Policy and Corporate Value (A Meta-Analysis)}

Tifani Titah Dwi Tyastari, Rosidi, Erwin Saraswati

Technical aspects are also the basis for investors to take a decision cannot be done due to inadequate research data; (2) based on the test results of the moderating effects, the effect of dividend policy on corporate value is moderated by the corporate value measurement model and the measurement model on dividend policy. That is because the test results using the moderating effect inconsistent measurement of the corporate value. Model measurement of the corporate value significantly moderating the effect of dividend policy on corporate value is Price to Book Value (PBV), Tobin's Q, and Market Value of Equity (MVE). Model measurements dividend policy significantly moderating the effect of dividend policy on corporate value is Dividend Payout Ratio (DPR) and the Dummy. Based on these results, it is evident that the inconsistencies in previous studies because of differences in the measurement of the dependent variable and independent variables. This is consistent with meta-analysis of studies that have been done before (Ahmed \& Courtis, 1999; Eny, 2013; Fanani, 2014; Handayani, 2015).

\section{Suggestions}

During the study, some of the limitations to be found are described below. For further research, it will be given some suggestions that can be used inimproving these limitations. Here's an explanation of these limitations and suggestions: (1) previous studies on the effect of the dividend policy and the corporate value does not display the value of r-statistics and values that can be converted into r-statistics, variable measurement data and detailed statistical results, thus it reducing the number of samples which can be processed into a meta-analysis. Future studies are expected to use the data for more research with measurement models are more varied, so as to find out the ratio or other types of measurements that affect the value of the company; (2) research in Indonesia mostly based on fundamental analysis, so less representing the actual capital market conditions that occurred in Indonesia. And to be able to assess a company must use fundamental analysis and technical analysis. Future studies are expected to use the research data using technical analysis to look at the corporate value, so the analysis of the effect of dividend policy on corporate value can be seen in its entirety.

\section{REFERENCES}

Abdullah, S. 2016. Free Cash Flow, Agency Theory, dan Signaling Theory: Konsep dan Riset Empiris. Jurnal Akuntansi dan Investasi, 3(2): 151-170.

Agustina, Y. 2011. Pengaruh Kepemilikan Manajerial, Kepemilikan Institusional, Kebijakan Dividen, Ukuran Perusahaan, Tingkat Suku Bunga terhadap Struktur Modal dan Nilai Perusahaan (Studi pada Perusahaan Manufaktur yang Terdaftar di BEI). Tesis. Fakultas Ekonomi Universitas Brawijaya Malang.

Aharony, J. \& Swary, I. 1980. Quarterly Dividends and Earnings Announcements and Stockholders' Returns: An Empirical Analysis. The Journal of Finance, 35(1): 1-12.

Ahmed, K. \& Courtis, J.K. 1999. Associations between Corporate Characteristics and Disclosure Levels in Annual Reports: A Meta-analysis. British Accounting Review, 31(1): 35-61.

Ansori, M. \& Denica H.N. 2010. Pengaruh Keputusan Investasi, Keputusan Pendanaan dan Kebijakan Dividen terhadap Nilai Perusahaan pada Perusahaan yang tergabung dalam Jakarta Islamic Index Studi pada Bursa Efek Indonesia (BEI). Analisis Manajemen, 4(2): 154-176.

Arifin, Z. 2005. Teori Keuangan dan Pasar Modal. Yogyakarta: Ekonisia.

Artini, S. \& Puspaningsih, A. 2011. Struktur Kepemilikan dan Struktur Modal terhadap Kebijakan Dividen dan Nilai Perusahaan. Jurnal Keuangan dan Perbankan, 15(1): 66-75.

Bakti, J.P. 2014. Pengaruh Kebijakan Dividen dan Profitabilitas terhadap Shareholders Wealth pada Perusahaan Transportasi yang Terdaftar di BEI Periode 2007-2012. Calyptra: Jurnal Ilmiah Mahasiswa Universitas Surabaya, 3(1): 1-19. 


\section{Jurnal Keuangan dan Perbankan | KEUANGAN}

Vol. 21, No. 3, Juli 2017: 344-355

Bernandhi, R. 2014. Pengaruh Kepemilikan Manajerial, Kepemilikan Institusional, Kebijakan Dividen, Leverage, dan Ukuran Perusahaan terhadap Nilai Perusahaan. Diponegoro Journal of Accounting, 3(1): 1-14.

Bhattacharya, S. 1979. Imperfect Information, Dividend Policy, and "The Bird in The Hand" Fallacy. The Bell Journal of Economics, 10(1): 259-270.

Dossugi, S. 2009. Analisis Faktor-faktor yang Memengaruhi Penciptaan Nilai pada Perusahaan-perusahaan di Bursa Efek Jakarta. Journal of Applied Finance and Accounting, 2(1): 6775.

Engombe, T.M. 2014. Dividend Policy and Its Impact on Corporate value: A Review of Theories and Empirical Evidence. Financial Analysis and Portfolio Management. University of Cape Town.

Eny, N. 2013. Analisis Meta: Faktor-faktor yang Memengaruhi Manajemen Laba di Indonesia. Disertasi. Universitas Brawijaya Malang.

Fanani, Z. 2014. Karakteristik Perusahaan dan Corporate Governance terhadap Manajemen Laba: Studi Analisis Meta. Jurnal Keuangan dan Perbankan, 18(2): 181-200.

Fanani, Z. 2016. Research Study Literature Using MetaAnalysis: Teori dan Aplikasi. Seminar Kolegial Pendidikan Profesional Berkelanjutan (PPL). Universitas Negeri Malang.

Fenandar, G.I. 2013. Pengaruh Keputusan Investasi, Keputusan Pendanaan dan Kebijakan Dividen terhadap Nilai Perusahaan. Diponegoro Journal of Accounting, 2(1): 1-10.

Gayatri, N.L.P.R. \& Mustanda, I.K. 2014. Pengaruh Struktur Modal, Kebijakan Dividen dan Keputusan Investasi Terhadap Nilai Perusahaan. E-Jurnal Manajemen Universitas Udayana, 3(6): 17001718.

Glass, G.V. 1976. Primary, Secondary, and Meta-Analysis of Results. Educational Researcher, 5(10): 3-8.

Gumanti, T.A. 2013. Kebijakan Dividen: Teori, Empiris, dan Implikasi. Yogyakarta: UPP STIM YKPM.

Handayani, C. 2015. Meta-analisis: Faktor-faktor Yang Memengaruhi Nilai Perusahaan Di Indonesia. Skripsi. Universitas Airlangga.
Harahap, L. \& Wardhani, R. 2012. Analisis Komprehensif Pengaruh Family Ownership, Masalah Keagenan, Kebijakan Dividen, Kebijakan Hutang, Corporate Governance dan Opportunity Growth terhadap Nilai Perusahaan. Tesis. Universitas Indonesia Jakarta.

Hardiningsih, P. 2009. Determinan Nilai Perusahaan. Jurnal Akuntansi dan Investasi, 5(2): 231-250.

Haruman, T. 2008. Pengaruh Struktur Kepemilikan terhadap Keputusan Keuangan dan Nilai Perusahaan Survey pada Perusahaan Manufaktur di PT Bursa Efek Indonesia. Simposium Nasional Akuntansi (SNA) XI.

Hashemijoo, M., Ardekani, A.M., \& Younesi, N. 2012. The Impact of Dividend Policy on Share Price Volatility in the Malaysian Stock Market. Journal of Business Studies Quarterly, 4(1): 111-129.

Hunter, J.E. \& Schmidt, F.L. 1990. Methods of Meta-analysis: Correcting Error and Bias in Research Findings. Beverly Hills, CA: Sage.

Hutami, R.P. 2012. Pengaruh Dividend Per Share, Return On Equity dan Net Profit Margin terhadap Harga Saham Perusahaan Industri Manufaktur yang Tercatat di Bursa Efek Indonesia Periode 2006-2010. Nominal: Barometer Riset Akuntansi dan Manajemen, 1(1): 104-123.

Instanti, S.L.W. 2013. Pengaruh Kebijakan Dividen terhadap Harga Saham pada Perusahaan LQ 45. Potensio, 19(1): 7-13.

Juhandi, N. 2013. Faktor Internal dan Struktur Kepemilikan Saham terhadap Kebijakan Dividen serta Dampaknya pada Nilai Perusahaan (Studi pada Perusahaan Manufaktur terdaftar di Bursa Efek Indonesia). Disertasi. Fakultas Ekonomi dan Bisnis Universitas Brawijaya Malang.

Kostyuk, D. 2006. Dividend Payout: It's Impact on Corporate Value. Thesis. National University KyivMohyla Academy.

Lintner, J. 1956. Distribution of Incomes of Corporations among Dividends, Retained Earnings, and Taxes. The American Economic Review, 46(2): 97-113.

Lipsey, M.W. \& Wilson, D.B. 2001. Practical Meta-analysis. Applied Social Research Methods. California: Sage Publications. 


\section{Dividend Policy and Corporate Value (A Meta-Analysis)}

Tifani Titah Dwi Tyastari, Rosidi, Erwin Saraswati

Manurung, A.H. 2012. Teori Keuangan Perusahaan. Jakarta: PT Adler Manurung Press.

Martikarini, N. 2012. Pengaruh Profitabilitas, Kebijakan Hutang, dan Dividen terhadap Nilai Perusahaan Manufaktur yang Terdaftar di Bursa Efek Indonesia Periode 2009-2011. Tesis. Program Studi Akuntansi Universitas Gunadarma.

Megginson, W.L. 1997. Corporate Finance Theory. Boston: Addison-Wesley.

Mesrawati. 2013. Analisis Faktor-faktor yang Memengaruhi Nilai Perusahaan dengan Kepemilikan Manajerial sebagai Variabel Moderating di Perusahaan Manufaktur dalam Sektor Barang Konsumsi yang Terdaftar di Bursa Efek Indonesia. Tesis. Universitas Sumatera Utara Medan.

Modigliani, F. \& Miller, M.H. 1961. Dividend Policy Growth and the Valuation of Shares. Journal of Business, 34(4): 411-433.

Murekefu, T.M. \& Ouma, O.P. 2012. The Relationship between Dividend Payout and Firm Performance: A Study of Listed Companies in Kenya. European Scientific Journal, 8(9).

Ningsih, P.P. \& Indarti, I. 2012. Pengaruh Keputusan Investasi, Keputusan Pendanaan, dan Kebijakan Dividen terhadap Nilai Perusahaan (Studi Kasus pada Perusahaan Manufaktur yang Terdaftar di Bursa Efek Indonesia Periode 2007-2009). Jurnal Kajian Akuntansi dan Bisnis, 1(1): 1-23.

Prathama, A. 2013. Pengaruh Kebijakan Dividen, Keputusan Pendanaan, Profitabilitas, dan Struktur Kepemilikan terhadap Nilai Perusahaan. Tesis. Universitas Katolik Indonesia Atmajaya Jakarta.

Putri, A.D. 2011. Dampak Good Corporate Governance dan Budaya Organisasi pada Pengaruh Kebijakan Dividen terhadap Manajemen Laba serta Konsekuensinya pada Nilai Perusahaan (Studi pada Perusahaan Publik di Indonesia). Disertasi. Fakultas Ekonomi Universitas Brawijaya Malang.
Putri, P.I. 2013. Pengaruh EPS, DER, Kebijakan Deviden, dan Resiko Sistematis terhadap Harga Saham Perusahaan yang Terdaftar di BEI (Studi pada Perusahaan yang Masuk dalam Indeks LQ45 di Bursa Efek Indonesia Periode 2009-2011). Jurnal Ilmiah Mahasiswa, 1(2).

Rahmandia, F. 2013. Faktor-faktor yang Memengaruhi Harga Saham Perusahaan di Sektor Industri Barang Konsumsi yang terdaftar di BEI Periode 2007-2011. Calyptra: Jurnal Ilmiah Mahasiswa Universitas Surabaya, 2(1).

Rakhimsyah, L.A. \& Gunawan, B. 2011. Pengaruh Keputusan Investasi, Keputusan Pendanaan, Kebijakan Dividen dan Tingkat Suku Bunga terhadap Nilai Perusahaan. InFestasi, 7(1).

Sari, O.T. 2013. Pengaruh Keputusan Investasi, Keputusan Pendanaan dan Kebijakan Dividen terhadap Nilai Perusahaan. Management Analysis Journal, 2(2).

Sofyaningsih, S. \& Hardiningsih, P. 2011. Struktur Kepemilikan, Kebijakan Dividen, Kebijakan Utang dan Nilai Perusahaan. Dinamika Keuangan dan Perbankan, 3(1): 68-87.

Tawi, M.S. 2008. Konsep Meta-Analysis. https:// syehaceh.wordpress. com/2008/05/15/konsepmeta-analysis/. Diakses pada tanggal: 1 November 2015.

Ulya, H. 2014. Analisis Pengaruh Kebijakan Hutang, Kebijakan Dividen, Profitabilitas, Kinerja Perusahaan dan Keputusan Investasi terhadap Nilai Perusahaan pada Perusahaan Manufaktur yang Terdaftar di Bursa Efek Indonesia (BEI) Tahun 2009-2011. Tesis. Jurusan Manajemen Fakultas Ekonomi dan Bisnis Universitas Dian Nuswantoro Semarang.

Weston, J.F. \& Copeland, T.E. 1997. Manajemen Keuangan. Edisi Kesembilan. Jakarta: Binarupa Aksara.

Wijaya, L.R.P. 2010. Implikasi Keputusan Investasi, Keputusan Pendanaan, dan Kebijakan Dividen terhadap Nilai Perusahaan. Thesis. Universitas Sebelas Maret. 